\title{
New data on distribution of the endangered species Viola jooi (Violaceae) in Ukraine
}

\author{
Jan Roleček ${ }^{1,2}$, Pavel Dřevojan ${ }^{1}$ \\ ${ }^{1}$ Department of Botany and Zoology, Faculty of Science, Masaryk University \\ 2 Kotlářská, Brno 611 37, Czech Republic \\ ${ }^{2}$ Department of Vegetation Ecology, Institute of Botany, Czech Academy of Sciences \\ 25/27 Lidická, Brno 657 20, Czech Republic \\ honza.rolecek@centrum.cz \\ pavel.drevojan@seznam.cz
}

Roleček J., Dřevojan P. 2019. New data on distribution of the endangered species Viola jooi (Violaceae) in Ukraine. Ukrainian Botanical Journal, 76(6): 526-532.

Abstract. Here we report the third extant site of Viola jooi in Ukraine. The species was found on an open calcareous scree in the valley of the Tlumach stream near Ostrynia village (Tlumach District, Ivano-Frankivsk Region). Vegetation of the scree may be classified to a broadly circumscribed alliance Stipion calamagrostis or to its east-central European counterpart Teucrion montani (class Thlaspietea rotundifolii). Moreover, our survey of Ukrainian and Polish herbaria revealed several specimens collected during the 1930s at two sites not yet mentioned in the literature, with one of the sites situated near our newly found site. We see a need for a thorough field survey of the historical, extant and other suitable sites of the species in the area of its present distribution in the Ukraine. Despite the new finds, Viola jooi remains one of the rarest relicts of the ancient heliophilous flora of the Volyn-Podolian Upland, pointing to its peri-Alpidic biogeographical affinities. Conservation priorities should be in line with this status.

Keywords: endangered species, plant distribution, Podnistrovia, Pokuttia, relict, scree vegetation

Submitted 08 October 2019. Published 29 December 2019

Ролечек Я. ${ }^{1,2}$, Држевоян П. ${ }^{1}$ 2019. Нові дані щодо поширення зникаючого виду Viola jooi (Violaceae) в Україні. Український ботанічний журнал, 76(6): 526-532.

'Університет Масарика вул. Котляржська 37, Брно 611 37, Чеська Республіка

${ }^{2}$ Інститут ботаніки, Академія Наук Чеської Республіки вул. Лідіцька 25/27, Брно 657 20, Чеська Республіка

Реферат. У статті повідомляється про третю знахідку Viola jooi в Україні. Вид був знайдений на відкритих вапнякових осипах у долині р. Тлумач поблизу с. Остриня (Тлумацький район, Івано-Франківська область). Рослинність цих осипів може бути віднесена до союзу Stipion calamagrostis у широкому розумінні або до його східноцентральноєвропейського відповідника Teucrion montani (клас Thlaspietea rotundifolii). Крім того, у матеріалах гербаріїв з України та Польщі було знайдено декілька зразків, зібраних протягом 1930-х років у двох місцезнаходженнях, які раніше не наводилися в літературі, а одне з цих місцезнаходжень розташоване поблизу нещодавно знайденого нами локалітету. Отже, потрібно проводити ретельні польові дослідження як історичних, так і теперішніх, а також інших можливих локалітетів виду в межах регіону його сучасного поширення в Україні. Незважаючи на нові знахідки, Viola jooi залишається одним із найрідкісніших реліктів давньої геліофільної флори Волино-Подільської височини, що вказує на її пери-альпідні (периферійні до зон Альпійського орогенезу) біогеографічні зв'язки. Пріоритети охорони цього виду мають відповідати його статусу.

Ключові слова: зникаючий вид, поширення рослин, Подністров'я, Покуття, релікт, рослинність осипів

(C) 2019 J. Roleček, P. Dřevojan. Published by the M.G. Kholodny Institute of Botany, NAS of Ukraine. This is an open access article under the terms of the Creative Commons Attribution License (http://creativecommons.org/licenses/by/4.0/), which permits use, distribution, and reproduction in any medium, provided the original work is properly cited 


\section{Introduction}

Violajooi Janka is a rare species with a narrow distribution range, encompassing mainly the Eastern and Southern Carpathians in Romania. Outside Romania, a single site was reported from Serbia (Homoljske Planine Mts, Southern Carpathians) and two sites from Ukraine (Niketić et al., 2015). The Ukrainian sites are situated in the Pokuttia historical region near Chortovets and Harasymiv villages (Shelyag-Sosonko et al., 1980; Didukh, 2009), about $130 \mathrm{~km}$ north of the nearest sites in north-eastern Romania (cf. Niketić et al., 2015). The species is classified as vulnerable in the Red Data Book of Ukraine (Didukh, 2009) and as rare in the Romanian red list (Oltean et al., 1994). Its estimated threat status in Serbia is critically endangered species (Niketić et al., 2015). Habitats of the species in Ukraine include mainly gypsum outcrops with steppe grassland vegetation dominated by Carex humilis, Helictotrichon desertorum and Sesleria heuflerana, where it is accompanied by other rare ecological specialists such as Draba podolica (Schivereckia podolica) and Thalictrum petaloideum (incl. T. podolicum) (Koczwara, 1931; Didukh, 2009; Roleček et al., 2019).

Discovery of Viola jooi within the present-day territory of Ukraine has been ascribed to the Polish botanist Tadeusz Wilczyński (Koczwara, 1931; Zabłocki, 1947). Koczwara himself reported $V$.jooi from three phytosociological relevés recorded in June 1927 near Chortovets village on gypsum outcrops by the road to Obertyn (Koczwara, 1931; Fig. 1). The place likely corresponds to the Boldy site (also called Zholob) where the species is still present (Didukh, 2009). There are multiple herbarium specimens from this site in Krakow (KRA, KRAM), Lviv (LWS) and Kyiv (KW) herbaria, the oldest one coming from 1928 (see Overview of the studied herbarium specimens). Another site reported in the Red Data Book of Ukraine is located 10 kilometres to the north-west, on slopes of a gypsum sinkhole between Zhabokruky, Harasymiv and Zhyvachiv villages (Ya.P. Didukh pers. comm.; Fig. 1). A single specimen from this site is present in $\mathrm{KW}$.

The aim of this paper is to report a new site of Violajooi in Ukraine, which was found during a field trip in April 2019, and to provide additional new data on species' distribution retrieved from the literature and herbaria. These findings change the picture of distribution of $V$.jooi in the country.

\section{Study area}

The study area (Fig. 1) is situated in the northern part of the historical region of Pokuttia, which is a part of a physiographic region of the PokutianBessarabian Upland (IEU, 2019). It is predominantly built of calcareous sediments of the Neogene and Cretaceous age, mainly gypsum and marlstones (Vashchenko et al., 2007). The landscape is mildly undulating and largely used as farmlands. Incised valleys of the Dniester and its tributaries provide suitable habitats for the remnants of natural and seminatural non-forest vegetation, such as steppe grasslands, vegetation of rocky outcrops and screes (Koczwara, 1931; Didukh, Korotchenko, 2000; Didukh, Vasheniak, 2018; Roleček et al., 2019). Karst features, particularly sinkholes, developed in the Neogene gypsum deposits, provide additional habitats for these vegetation types (Didukh, Pavliuk, 2008).

\section{Methods}

Taxonomic concepts and nomenclature of vascular plant taxa follow Euro +Med PlantBase (2006-onward), with the exception of Ligularia glauca, for which we use the concept of Flora Europaea (Tutin et al., 1976). Syntaxonomic nomenclature follows Mucina et al. (2016); full references are provided for syntaxa not included in this source. Vegetation composition was recorded using $2 \times 2 \mathrm{~m}$ plot and standard phytosociological methodology, with the extended Braun-Blanquet scale used for species cover-abundance estimation (Dengler et al., 2008). Acronyms of herbaria follow Index Herbariorum (Thiers, 2008-onward).

\section{Results}

A new site of Viola jooi was found during a survey of steppe vegetation on steep slopes of the valley of Tlumach stream near Ostrynia village (Tlumach District, Ivano-Frankivsk Region, Western Ukraine; Fig. 1). Herbarium vouchers are deposited in the Herbarium of the Masaryk University (BRNU) in Brno. Several dozens of individuals were found on the south-west facing open marlstone scree (Fig. 2) and in adjacent dry grasslands. Species composition of the scree vegetation was recorded using the following phytosociological relevé.

Ukraine, Ivano-Frankivsk Region, Tlumach District, Ostrynia village, steep slope above right bank of the Tlumach stream, latitude $48^{\circ} 55^{\prime} 40.9^{\prime \prime} \mathrm{N}$, longitude $24^{\circ} 59^{\prime} 12.3^{\prime \prime} \mathrm{E}$ (WGS-84), altitude $250 \mathrm{~m}$ a.s.l., plot size 


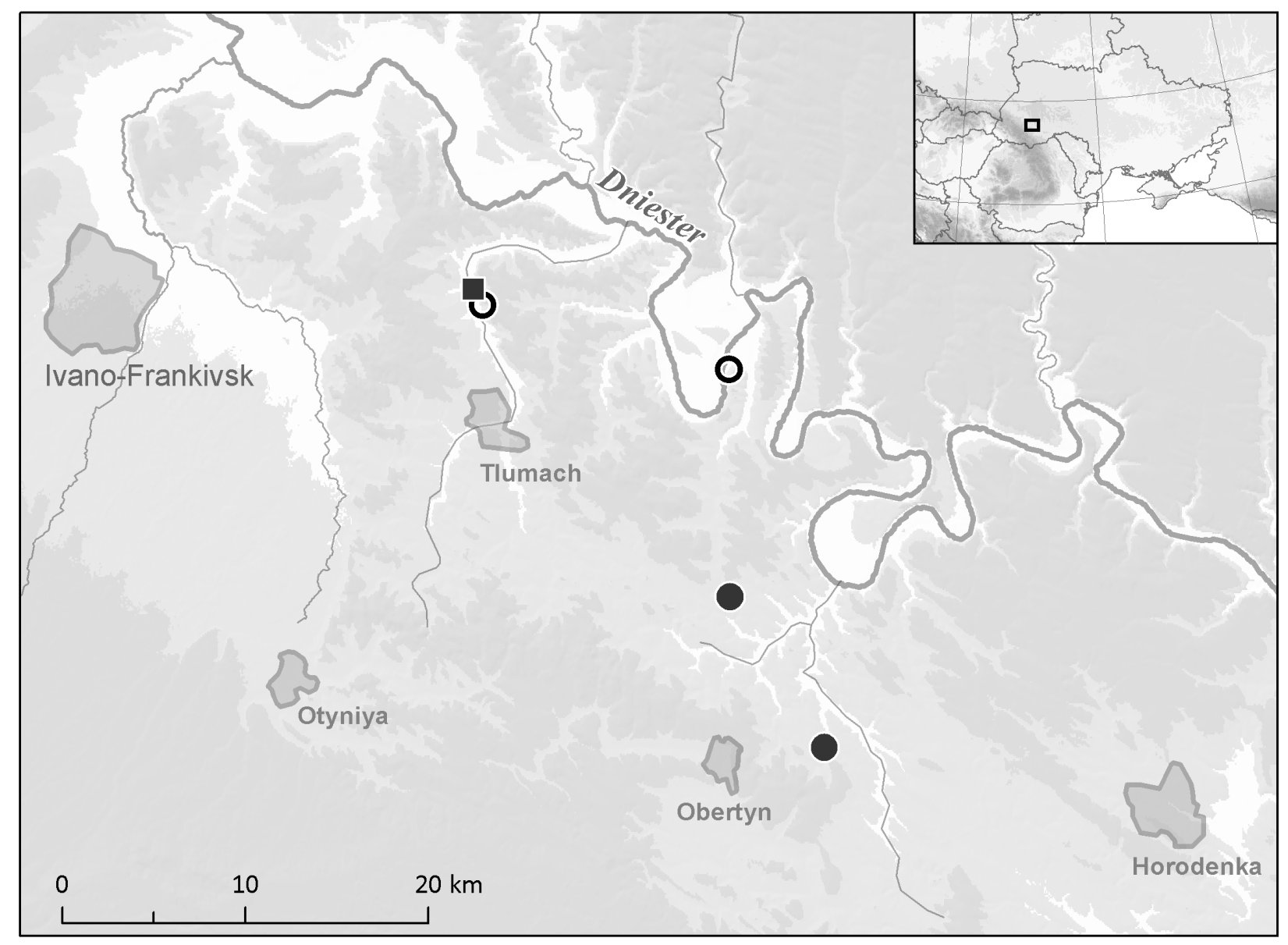

Fig. 1. Distribution of Viola jooi in Ukraine. Full square - newly found extant site; full circles - extant sites reported by Didukh (2009); empty circles - sites of the newly discovered herbarium specimens collected in the 1930s

$4 \mathrm{~m}^{2}$, slope inclination $40^{\circ}$, slope aspect $200^{\circ}$, cover of herb layer $5 \%$, cover of moss layer $<1 \%$. Authors: J. Roleček \& P. Dřevojan. Date: 17 April 2019.

Herb layer: Teucrium montanum 1, Allium lusitanicum + , Asperula cynanchica +, Bupleurum falcatum +, Euphorbia cyparissias + , Ranunculus breyninus + , Salvia verticillata + , Securigera varia + , Teucrium chamaedrys + , Viola jooi + , Arrhenatherum elatius r, Daucus carota $\mathrm{r}$, Echium vulgare r, Sanguisorba minor r.

During our subsequent survey of botanical literature and herbaria we identified two additional sites not yet reported in the relevant Ukrainian and Polish literature (Zabłocki, 1947; Shelyag-Sosonko et al.; 1980; Didukh, 2009):

i) Suchodól [= Sukhodil] village, Dniester valley near Brzezina grange (J. Mądalski, 1934, KRAM);

ii) slopes above Pałahicze $[=$ Palahychi $]$ village (J. Mądalski, 1936, KRAM).
Detailed information on the herbarium specimens are provided in Appendix 1. Summary data of the known past and present localities of Viola jooi in Ukraine is provided in Fig. 1.

\section{Discussion}

\section{New finds}

While the latest overview of the distribution of Viola jooi in Ukraine (Didukh, 2009) mentions two historical sites (both reported as still existing), we discovered three additional sites. The extant site near Ostrynia, which was found during a field trip in 2019, represents the northernmost point of species' known distribution (cf. Niketić et al., 2015).

Perhaps even bigger surprise was a discovery of two historical sites of Viola jooi in the herbarium of the W. Szafer Institute of Botany, Polish Academy of 


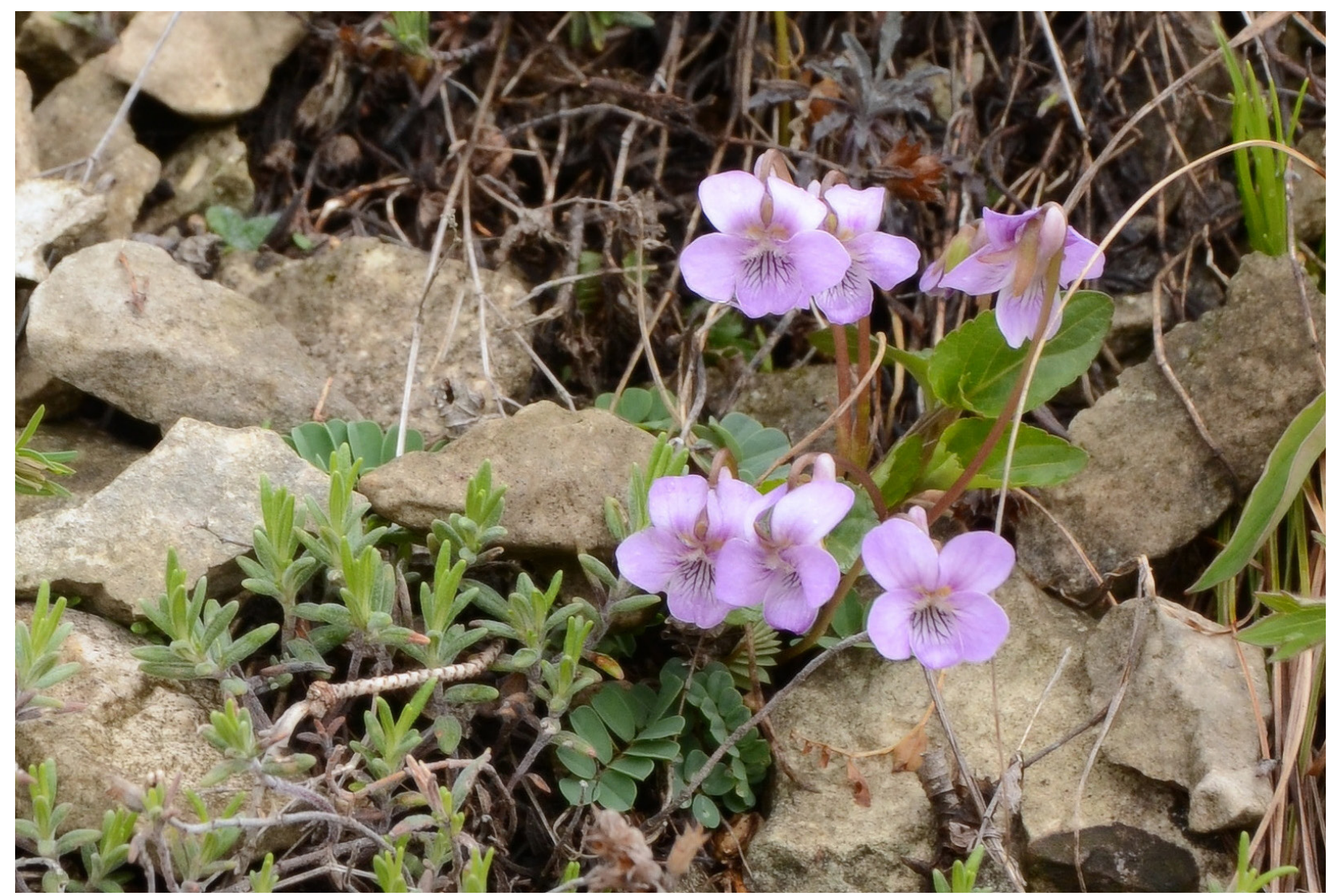

Fig. 2. Viola jooi at its newly found site near Ostrynia village. Teucrium montanum, a dominant species of the habitat, and Securigera varia are also visible

Sciences, Krakow (KRAM), kindly checked by Agnieszka Nikel. Respective specimens were collected by the Polish botanist Józef Mądalski in the 1930s, when the whole area of interest was a part of Poland. Mądalski worked at Jan Kazimierz University in Lviv. After the expulsion of Poles from the region by the end of World War II he moved to Wrocław, but later he handed over his personal herbarium to Krakow (see https://pl.wikipedia.org/wiki/Józef_Mądalski).

The site near Palahychi is located just about $1 \mathrm{~km}$ south-west of the extant site found by us and thus may be considered as a single larger site. However, site conditions of the two places may differ, as the area provides outcrops of not only Cretaceous marlstones, but also of Neogene gypsum. The other site near Sukhodil is the first known place of occurrence of Viola jooi in the Dniester valley, which has been recognized as an important refugium for non-forest species (Didukh, Vasheniak, 2018). Additional habitats suitable for $V$. jooi still occur in the surroundings of both historical sites and we assume that a focused field survey might Український ботанічний журнал, 2019, 76(6) bring new interesting findings. The search in other relevant herbaria in Ukraine and Poland (KRA, KW, LW, LWS) brought no new information on distribution of the species. It should also be noted that $V$. jooi was repeatedly reported from the Ukrainian Carpathians (Klokov, 1955; Tzvelev, 1996; Novikoff, Hurdu, 2015) listed it among doubtful taxa for this region. However, the respective record is surely erroneous, because it was based on an incorrect geographical interpretation of the Pokuttia region by Klokov (1955), which was probably followed by Tzvelev (1996).

We hope that the new find reported here will stimulate interest in the species and that nature conservation priorities will meet its status and needs.

\section{Biogeography}

Despite the new finds, Viola jooi remains one of the rarest relicts of the ancient heliophilous flora of the Volyn-Podolian Upland. This flora includes various biogeographical and ecological elements, among which the continental steppe element and Central European 
(in a wide sense) montane element belong to most characteristic ones (Szafer, 1923; Gajewski, 1937; Zaveryukha, 1985; Didukh, Vasheniak, 2018). Viola jooi clearly belongs to the latter, showing dealpine ecological features and peri-Alpidic (in this case, peri-Carpathian) distribution. In this respect, the co-occurring Teucrium montanum and Ranunculus breyninus show certain similarities.

Although some authors (e.g. Szafer, 1923) suggested the Tertiary age for these relicts, we assume that extensive climatic fluctuations connected with multiple Pleistocene glacial-interglacial cycles (Ehlers, Gibbard, 2011) led to profound changes of species' distribution ranges. Therefore, the current distribution patterns of Viola jooi and other heliophilous relicts were probably determined rather by the extent of their ranges during the last Ice Age (Late Pleistocene) or early Holocene and by the rate of their retreat during the Holocene forest spread. Admittedly, in some cases (e.g. the species with extremely disjunct ranges such as Ligularia glauca and Thalictrum petaloideum) earlier events might have played more important roles.

\section{Vegetation}

Vegetation of the scree with Viola jooi in the Tlumach valley may be classified to a broadly circumscribed alliance Stipion calamagrostis (class Thlaspietea rotundifolii), which according to Mucina et al. (2016) includes the alliance Teucrion montani. The latter alliance is an alternative option for the classification of vegetation of low-altitude calcareous screes in east-central Europe (Valachovič et al., 1997). None of these alliances has been reported from Ukraine yet (Solomakha, 2008, Dubyna et al., 2019).

Previously, the species was reported from Ukraine only from dry grasslands on gypsum bedrock (Koczwara, 1931; Didukh, 2009). These have been classified to the association Ranunculo zapalowiczii-Helictotrichonetum desertori described by Kukovitsia et al. (1994). The association has been assigned to different higher syntaxa by different authors (Kukovitsia et al., 1994; Didukh, Korotchenko, 2000; Didukh, Vasheniak, 2018). Based on its species composition, physiognomy and ecology, we prefer its original assignment to the order of rocky steppes Stipo pulcherrimae-Festucetalia pallentis and the alliance Galio campanulati-Poion versicoloris or to its more broadly conceived analogue Bromo pannoniciFestucion csikhegyensis (see Mucina et al., 2016).

In Romania Viola jooi occupies mainly colline to alpine rock grasslands, outcrops and screes on calcareous bedrock, often dominated by Festuca pallens, Helictotrichon decorum, Sesleria heufleriana, S. rigida, Teucrium montanum or Thymus comosus (Csürös, Pop, 1965; Doniță et al., 2005; Šmarda, 2005). The new site by Ostrynia therefore fits well the ecological amplitude of the species.

\section{Overview of the studied herbarium specimens}

Tlumach Region: Ostrynia: SW-facing open marlstone scree and adjacent dry grasslands on the steep slope above the right bank of the Tlumach stream $1.2 \mathrm{~km}$ ENE from the church, 250 a.s.1., $48^{\circ} 55^{\prime} 40.9^{\prime \prime} \mathrm{N}$

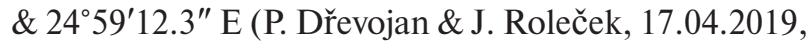
BRNU). - Pałahicze k. Tłumacza, na halawie na pd. stoku wzgórza na pd. od koty 331 (J. Mądalski, 16.04.1936, KRAM). - Suchodół, folwark Brzezina, na ścianie pr. brzegu Dniestru w jasnych zaroślach wśród lasu (J. Mądalski, 20.07.1934, KRAM). Suchodół koło Tłumacza, na lesistej ścianie prawego brzegu jaru Dniestru w miejscach jasnych, stepowych koło dawnego folw. Brzezina (J. Mądalski, 07.08.1936, KRAM). - Ivano-Frankovskaya obl., Tlumachskiy r-n. s. Gerasimov, severnyye krutyye sklony, form. Seslerieta heuflerianae [Ивано-Франковская обл., Тлумачский p-н, с. Герасимов, северные крутые склоны, форм. Seslerieta heuflerianae] (Ya.P. Didukh, 18.05.1979, KW).

Horodenka Region: Czortowiec - step (J. Dobrzańska, 29.05.1928, KRA). - Podole: Czortowiec koło Winogradu. Skałki stepowe (Anonymous [Wycieczka Inst. Bot. U. J.] 29.05.1928, KRAM). Pokucie step.: Czortowiec, step z Avena Besseri na stromem wzgórzu gipsowem (B. Pawłowski, 29.05.1928, KRAM). - Pokucie step.: Czortowiec. Step z Avena Besseri na stromem zboczu gipsowem (B. Pawłowski, 29.05.1928, KRAM). - Pokucie stepowe. Czortowiec (pow. Horodeński). Step z Avena Besseri na gipsowem, stromem zboczu (B. Pawłowski, 29.05.1928, KRA). - Pokucie; Czortowiec (A. Kozłowska, 30.05.1928, KRAM). - Czortowiec koło Obertyna, na stromych halawach na pd. zach. od wsi (J. Mądalski, 25.04.1934, KRAM, KW). - Ivano-Frankovskaya obl. Gorodenkovskiy r-n. s. Chortovets. Boldy. Kamenistyye obnazheniya i stepnyye sklony [Ивано-Франковская обл. Городенковский р-н. с. Чертовец. Болды. Каменистые обнажения и степные склоны] (Yu.R. Shelyag-Sosonko \& Ya.P. Didukh, 31.07.1977, KW). Ivano-Frankovskaya obl, Gorodenkovskiy r-n. s. Nazarenkovo [= Chortovets], ur. Galdy [= Boldy]. Severnyye krutyye sklony, formatsiya Helictotrichoneta besserii [Ивано-Франковская обл, Городенковский 
p-н. с. Назаренково [= Чортовец], ур. Галды [= Болды]. Северные крутые склоны, формация Helictotrichoneta besserii] (Ya.P. Didukh, 17.05.1979, KW). - Ivano-Frankivs'ka obl., Horodenkivs'kyy r-n., okol. s. Chortovets', ur. Baudy [= Boldy], vapnyakovi skeli [Івано-Франківська обл., Городенківський p-н., окол. с. Чортовець, ур. Бауди [= Болди], вапнякові скелі] (M.M. Fedoronchuk \& Ya.P. Didukh, 30.04.2007, KW).

\section{Acknowledgements}

We are indebted to Lubov Borsukiewicz, Illia I. Chorney, Yakiv P. Didukh, Agnieszka Nikel and Marcin Nobis for searching local herbaria and providing information on the species. Our thanks also go to Volodymyr Buchko who kindly provided logistic support during our field research, Ondřej Hájek for drawing the map, and Anna Kuzemko for useful comments.

\section{REFERENCES}

Csürös Ş., Pop I. 1965. Considerații generale asupra florei şi vegetației masivelor calcaroase din munții apuseni. Contributii Botanice, (1965): 113-131.

Dengler J., Chytrý M., Ewald J. 2008. Phytosociology. In: Encyclopedia of ecology, vol. 4. General ecology. Eds S.E. Jørgensen, B.D. Fath. Oxford: Elsevier, pp. 2767-2779.

Didukh Ya.P. 2009. Viola jooi. In: Chervona knyha Ukrainy. Roslynnyi svit (Red Data Book of Ukraine. Plant kingdom). Ed. Ya.P. Didukh. Kyiv: Globalconsulting, p. 620. [Дідух Я.П. 2009. Viola jooi. В кн.: Червона книга України. Рослинний світ. Ред. Я.П. Дідух. Київ: Глобалконсалтинг, с. 620].

Didukh Ya.P., Korotchenko I.A. 2000. Ukrainian Phytosociological Collection. Series A, Phytosociology, 16(1): 3-15. [Дідух Я.П., Коротченко І.А. 2000. Класифікація степової рослинності Покуття. Украӥнський фітоценологічний збірник. Серія А. Фітосоціологія, 16(1): 3-15].

Didukh Ya.P., Pavliuk V.S. 2008. Ukrainian Botanical Journal, 65(4): 495-503. [Дідух Я.П., Павлюк В.С. 2008. Ландшафтно-екологічні особливості розподілу рослинних уруповань у карстових воронках Прутсько-Дністровського лісостепу. Український ботанічний журнал, 65(4): 495-503].

Didukh Ya.P., Vasheniak Yu.A. 2018. Vegetation of limestone outcrops in Western and Central Podillia (Ukraine). Tuexenia, 38: 419-444. https://doi. org/10.14471/2018.38.023

Doniță N., Popescu A., Paucă-Comănescu M., Mihăilescu S., Biriş I.A. 2005. Habitatele din România. Bucureşti: Editura Tehnică Silvică, 496 pp.

Dubyna D.V., Dzyuba T.P., Yemelyanova S.M., Bagrikova N.O., Borysova O.V., Borsukevych L.M., VynokurovD.S., GaponS.V., Gapon Yu.V., DavydovD.A., Dvoretskyy T.V., Didukh Ya.P., Zhmud O.I., Kozyr M.S., Konishchuk V.V., Kuzemko A.A., Pashkevych N.A., Ryff L.E., Solomakha V.A., Felbaba-Klushyna L.M.,
Fitsaylo T.V., Chorna H.A., Chorney I.I., ShelyagSosonko Yu.R., Yakushenko D.M. 2019. Prodromus roslynnosti Ukrainy (Prodrome of the vegetation of Ukraine). Eds D.V. Dubyna, T.P. Dzyuba. Kyiv: Naukova Dumka, 782 pp. [Дубина Д.В., Дзюба Т.П., Емельянова С.М., Багрікова Н.О., Борисова О.В., Борсукевич Л.М., Винокуров Д.С., Гапон С.В., Гапон Ю.В., Давидов Д.А., Дворецький Т.В., Дідух Я.П., Жмуд О.І., Козир М.С., Конішук В.В., Куземко А.А., Пашкевич Н.А., Рифф Л.Е., Соломаха В.А., Фельбаба-Клушина Л.М., Фіцайло Т.В., Чорна Г.А., Чорней I.I., Шеляг-Сосонко Ю.Р., Якушенко Д.М. 2019. Продромус рослинності України. Ред. Д.В. Дубина, Т.П. Дзюба. Київ: Наукова думка, 782 с.].

Ehlers J., Gibbard P. 2011. Quaternary Glaciation. In: Encyclopedia of Snow, Ice and Glaciers. Encyclopedia of Earth Sciences Series. Eds V.P. Singh, P. Singh, U.K. Haritashya. Dordrecht: Springer, pp. 873882. https://doi.org/10.1007/978-90-481-2642-2_423

Euro+Med PlantBase - the information resource for EuroMediterranean plant diversity. 2006-onward. Available at: http://ww2.bgbm.org/EuroPlusMed/ (Accessed 16 August 2019).

Gajewski W. 1937. Elementy flory polskiego Podola. Planta Polonica, 5: 1-210.

IEU. Internet Encyclopedia of Ukraine. 2019. Available at: http://www.encyclopediaofukraine.com/default.asp (Accessed 30 July 2019).

Klokov M.V. 1955. Violaceae. In: Flora URSR, vol. 7. Eds M.V. Klokov, O.D. Visyulina. Kyiv: Vydavnytstvo Akademii nauk Ukrayinskoyi RSR, pp. 337-382. [Клоков М.В. 1955. Фіалкові - Violaceae Juss. В кн.: Флора УРСР, т. 7. Ред. М.В. Клоков, О.Д. Вісюліна. Київ: Видавництво Академії наук Української РСР, c. 337-382].

Koczwara M. 1931. Zespoły stepowe Podola Pokuckiego. Prace Instytutu Geografii im. E. Romera, 12: 35-79.

Kukovitsia H.S., Movchan Ya.I., Solomakha V.A., ShelyagSosonko Yu.R. 1994. Ukrainian Botanical Journal, 51 (2-3): 35-48. [Куковиця Г.С., Мовчан Я.І., Соломаха В.А., Шеляг-Сосонко Ю.Р. 1994. Синтаксономія лучних степів Західного Поділля (Україна). Український ботанічний журнал, 51(2-3): 35-48].

Mucina L., Bültmann H., Dierssen K., Theurillat J.-P., Raus T., Čarni A., Šumberová K., Willner W., Dengler J., Gavilán García R., Chytrý M., Hájek M., Di Pietro R., Iakushenko D., Pallas J., Daniëls F.J.A., Bergmeier E., Santos Guerra A., Ermakov N., Valachovič M., Schaminée J.H.J., Lysenko T., Didukh Ya.P., Pignatti S., Rodwell J.S., Capelo J., Weber H.E., Solomeshch A., Dimopoulos P., Aguiar C., Hennekens S.M., Tichý L. 2016. Vegetation of Europe: hierarchical floristic classification system of vascular plant, bryophyte, lichen, and algal communities. Applied Vegetation Science, 19 (Suppl. 1): 3-24. https://doi.org/10.1111/avsc.12257

Niketić M., Cikovac P., Barina Z., Pifkó D., Melovski L., Dukari S., Tomović G. 2015. Viola chelmea and Viola jooi (Violaceae), new species for the flora of Serbia and their distribution in the Balkan Peninsula and the Carpathians. Bulletin of the Natural History Museum, 8: 49-74. https:// doi.org/10.5937/bnhmb1508049N 
Nikitin V.V. 1996. Violaceae. In: Flora Europae Orientlis, vol. 9. Ed. N.N. Tzvelev. St. Petersburg: Mir i Semya-95, pp. 180-206. [Никитин В.В. 1996. Violaceae. В кн.: Флора Восточной Европы, т. 9. Ред. Н.Н. Цвелев. Санкт-Петербург: Мир и Семья-95, с. 180-206].

Novikoff A., Hurdu B.-I. 2015. A critical list of endemic vascular plants in the Ukrainian Carpathians. Contribuţii Botanice, 50: 43-91.

Oltean M., Negrean G., Popescu A., Roman N., Dihoru G., Sanda V., Mihăilescu S. 1994. Studii, sinteze, documentaţii de ecologie. Lista roșie a plantelor superioare din România. Bucureşti: Academia Română, Institutul de Biologie, $52 \mathrm{pp}$.

Roleček J., Hájek M., Dřevojan P., Prokešová H., Fajmon K., Těšitel J., Daněk P., Hájková P., Jongepierová I., Novák P., Poluyanov A.V., Shumska N.V., Chorney I.I. 2019. Gradients, species richness and biogeographical links of steppe grasslands in Western Podolia (Ukraine). Phytocoenologia, in press. https://doi.org/10.1127/ phyto/2019/0255

Shelyag-Sosonko Yu.R., Didukh Ya.P., Kukovitsia H.S. 1980. Ukrainian Botanical Journal, 37(3): 221-224. [Шеляг-Сосонко Ю.Р., Дідух Я.П., Куковиця Г.С. 1980. Поширення Viola jooi Janka на Україні. Український ботанічний журнал, 37(3): 221-224].

Solomakha V.A. 2008. Syntaksonomiya roslynnosti Ukrainy. Tretye nablyzhennya (Syntaxonomy of vegetation of Ukraine. Third approximation). Kyiv: Fitosotsiotsentr, 296 pр. [Соломаха В.А. 2008. Синтаксономія рослинності України. Третє наближення. Київ: Фітосоціоцентр, 296 с.].

Szafer W. 1923. Trzeciorzędowe rośliny górskie na wale scytyjskim w ostoi podolsko-wołyńskiej. Acta Societatis Botanicorum Poloniae, 1: 97-119.
Šmarda P. 2005. Biosystematická studie středoevropských kostřav Festuca ser. Psammophilae Pawlus: Ph. D. Diss. Brno, Masaryk University, 192 pp.

Thiers B. 2008-onward. Index Herbariorum. A global directory of public herbaria and associated staff. New York Botanical Garden's Virtual Herbarium. Available at: http:// sweetgum.nybg.org/science/ih Available at: http://sweetgum.nybg.org/science/ih/ (Accessed 16 August 2019).

Tutin T.G., Heywood V.H., Burges N.A., Moore D.M., Valentine D.H., Walters S.M., Webb D.A. 1976. Flora Europaea, vol. 4. Plantaginaceae to Compositae (and Rubiaceae). Cambridge: Cambridge University Press, $505 \mathrm{pp}$.

Valachovič M., Dierssen K., Dimopoulos P., Hadač E., Loidi J., Mucina L., Rossi G., Valle Tendero F., Tomaselli M. 1997. The vegetation on screes - a synopsis of higher syntaxa in Europe. Folia Geobotanica et Phytotaxonomica, 32(2): 173-192. https://doi. org/10.1007/BF02803739

Vashchenko V.O., Turchynova S.M., Turchynov I.I. 2007. Geological map and map of mineral resources of preQuaternary sediments. Carpathian Series. $M-35-X X V$ (Ivano-Frankivsk). Kyiv: Ukrainian State Geological Research Institute.

Zabłocki J. 1947. Flora Polska. Rośliny naczyniowe Polski $i$ ziem ościennych, vol. 6. Dwuliścienne. Wolnopłatkowe: Dwuokwiatowe. Rodzina: Violaceae, Fiołkowate. Krakow: Polska Akademia Umiejętności, $70 \mathrm{~s}$.

Zaverukha B.V. 1985. Flora Volyno-Podolii i ee genezis. Kiev: Naukova Dumka, 192 pp. [Заверуха Б.В. 1985. Флора Волыно-Подолии и ее генезис. Киев: Наукова думка, 192 c.].

Recommended for publication by Ya.P. Didukh 